\title{
Determinants of Economic Growth in Syria between 1980 and 2010
}

\author{
Adel Shakeeb MOHSEN ${ }^{*}$, Soo Y. CHUA ${ }^{* *}$, Che Normee CHE SAB ${ }^{* * *}$
}

\begin{abstract}
This study attempts to investigate the determinants of economic growth in Syria from 1980 to 2010. Results from the Johansen cointegration test indicate that public sector investment, private sector investment, exports, oil price, and population growth have positive long-run relationships with economic growth. Public sector investment has the biggest effect on economic growth. The Granger causality test results indicate bidirectional causality relationships between public sector investment, private sector investment, oil price, population growth and GDP in the short and long run. There are also bidirectional causality relationships between exports and GDP in the short run, and unidirectional causality relationship running from exports to GDP in the long run.
\end{abstract}

Keywords: economic growth, public sector, private sector, exports, VAR

JEL Code Classifications: O11, E20

UDC: 338.22(569.1)

DOI: https://doi.org/10.17015/ejbe.2017.019.05

\footnotetext{
Corresponding author. Lecturer, Valoris International University, Abidjan, Ivory Coast. Email: adelmhsen@hotmail.com.

** Associate professor, Universiti Sains Malaysia, Penang, Malaysia. Email: sychua@usm.my.

${ }^{* * *}$ Senior lecturer, Universiti Sains Malaysia, Penang, Malaysia. Email: csnormee@usm.my.
} 


\section{Introduction}

Syria is a middle-income developing country with a diversified economy. It depends mainly on agricultural products and mineral industries such as oil, natural gas and phosphates which are owned by the state. The agriculture, mineral and manufacturing sectors accounted for more than $40 \%$ of the GDP (CBS, 2010).

The Syrian economy is centrally planned since 1963 . However, the government has adopted the social market economy as its main economic strategy during the Tenth Syrian Five-Year Plan (2006-2010), and it has reduced its central planning gradually in line with the needs of economic development (SIED, 2011). Besides that, it has been working to reform the economy by opening up most sectors for private and foreign direct investment, diversifying the economy, reducing the country's dependence on oil and agriculture, opening private banks, establishing a stock market, and consolidating all the multiple exchange rates (USDS, 2011). However, Syria's economy is still facing serious growth challenges, such as poor performance of the public sector, declining oil production, deficits in the trade balance, high level of bureaucracy, and corruption. Furthermore, the rate of investment, and the levels of industrial and agricultural productivity are low due to a centrally planned economy (USDS, 2011).

Figure 1 shows the annual GDP growth rate in Syria from 1980 to 2010. In the early 1980s, GDP growth declined from $11.9 \%$ in 1980 to $-4.1 \%$ in 1984 due to the fall in oil prices, drop in export revenues, falling Arab financial assistances, depreciation of the Syrian pound, and the drought (Boris, 1987). However, the GDP growth rate increased in 1985, after a sudden increase in FDI inflows. In 1986 the GDP growth rate dropped to $-4.95 \%$ due to the fall in oil prices. Then, it moved up again in 1987 and 1988 due to the expansion of crude oil production and increase in oil prices. But in 1989 , it declined again to $-8.95 \%$ after a reduction in agricultural production. The GDP growth rate then increased to $7.9 \%$ in 1990 due to the rise in Syrian exports to the Soviet Union and Eastern European markets and the oil price increase.

During the first half of the 1990s, the resources of the state treasury increased from the Arab countries' assistances, agriculture sector returns, and the higher returns from crude oil exports, with increased oil production in that period (Kafri, 2004). These developments have positive impact on economic growth, and the average GDP growth rate was 7.99\% during the period of 1991-1995. However, the GDP growth was lower during the second half of the 1990s due to declining oil production, decreasing investment and increasing unemployment (Seifan, 2009). But in 1998, the economy improved after the increase in agriculture production, industrial output, FDI inflows and investment. While, in 1999 the GDP growth dropped to $-3.55 \%$ due to the drought as well as the declining oil production and investment. In 2000, oil prices and FDI inflows increased, which affected positively on economic growth. 
During the period of 2001 to 2010, the average GDP growth rate was about $4.3 \%$. This increase in the GDP growth was due to rising world oil prices and increasing FDI. Furthermore, the government's strategy to open up its economy to foreign investment, upgrade productivity, increase private sector involvement in economic development, and modernize industrial measures have boosted GDP growth (UNIDO, 2009). However, increasing inflow of Iraqi nationals into Syria after the Gulf War in 2003 was the main reason for rising inflationary pressures in the Syrian economy, which led to a decline in the rate of economic growth in 2003 to 1.6\% (ElQuqa et al. 2007). The GDP growth slowed to $3.2 \%$ in 2010 due to the fall in FDI, drought, and decreasing returns from the oil sector after a decline in oil production.

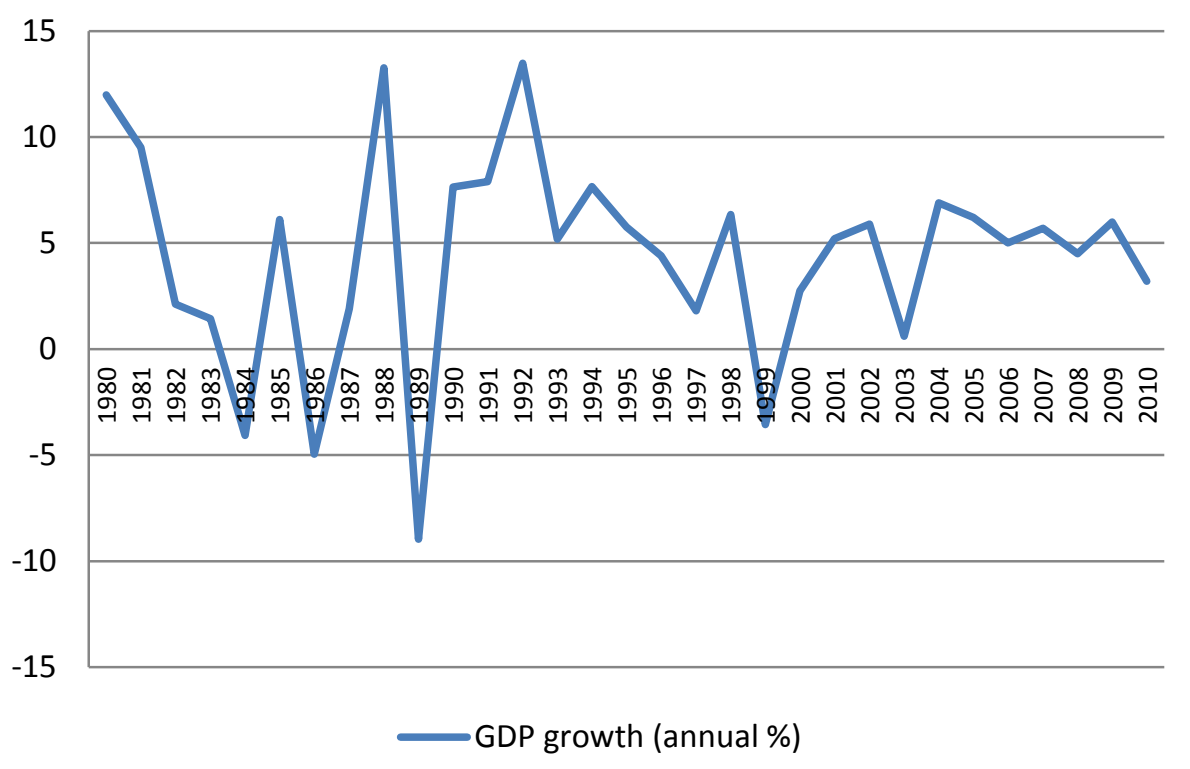

Figure 1. GDP growth rate in Syria (annual \%), 1980-2010

Source: World Bank.

If we take a quick look at the history of Syria's economic growth, from 1980 until 2010 , it seems that fluctuations in the rate of economic growth are a result of different factors such as changes in the public and private sector investments, foreign trade, population growth, oil price shocks, assistance from the Arab oil countries and drought. However, Syria was able to achieve reasonable growth rates during the last decade, in spite of the global financial crisis and the tense political atmosphere in the region (Seifan, 2009). Unfortunately, the war in Syria which started in 2011, has caused a huge damage on the social and economic condition of the country, and created a new situation quite different than in before 2011 . By the end of 2013, total volume of GDP loss since the start of the conflict was USD 70.88 
billion. Furthermore, many factories have been destroyed, the infrastructure has been damaged, the deficit in the trade balance has increased, the depreciation of the exchange rate of the Syrian pound has increased, and many oil wells have been controlled by the terrorists (SCPR, 2014).

The main objective of this study is to investigate the determinants of economic growth of Syria from 1980 to 2010, which may assist Syrian policy makers in rebuilding the Syrian economy after the war. The organization of this study is as follows. The following section is the literature review and Section 3 provides a brief discussion on the methodology. Section 4 reports the empirical results, and the conclusion and recommendations are presented in Section 5.

\section{Previous Studies}

Economic growth is one of the most important topics that have been discussed in many empirical studies. Some of these studies evaluated the role of public and private sector investment in economic growth, while others look at the effect of population, oil price and trade.

Most of the studies that investigated the relationship between public and private sector investments and economic growth indicated a positive relationship between investments and economic growth. These studies were based on different estimation techniques such as ordinary least square (Ghura, 1997), panel data analysis (Ramirez \& Nazmi, 2003), cointegration analysis (Aka, 2007; Kandenge, 2010; Fatima, 2012) and error correction model (Bukhari, Ali \& Saddaqat, 2007). However, Ibrahim (2000) argued that public investment is unproductive in Malaysia. Using annual data from 1961-1995, he found that the relationship between public capital formation and the growth rate of income per capita is negative, while private sector investment and export performance are related positively to economic growth in the country. Ghali (1998) also revealed that in the long run, public investment has a negative effect on private investment and growth in Tunisia, while in the short run public investment has no effect on growth, but it has a negative effect on private investment.

The relationship between population growth and economic growth were mixed. Some studies have found that population growth has a positive relationship with economic growth and this was supported by Savas (2008), Furuoka (2009) and Furuoka and Munir (2011). However, Afzal (2009) and Trang and Hieu (2011) found a negative relationship between population growth and economic growth. In addition, some of the studies such as Dawson and Tiffin (1998) for India, Thornton (2001) for seven Latin American countries, and Mushtaq (2006) for Pakistan indicated that there were no long run cointegrating relationship between population and economic growth. Furthermore, many studies have investigated the impact of oil price on economic growth. For example, Gisser and Goodwin (1986), Burbidge and Harrison (1984), Hamilton (1983), and Darby (1982), they found that 
oil price increases have a negative effect on the economic growth of oil importing countries. Besides, other studies such as Ito (2008), Aliyu (2009), Berument, Ceylan andDogan (2010), Yong et al. (2011), and Emami and Adibpour (2012) found that oil price has a positive effect on economic growth of oil exporting countries.

Moreover, many empirical studies, including Tyler (1981), Balassa (1985), Ram (1987), Krueger (1990), Khan and Saqib (1993), Sengupta and Espana (1994), AlYousif (1997), Shirazi and Abdul-Manap (2004), Abou-Stait (2005), Alhajhoj (2007), Hye and Boubaker (2011), Saad (2012), Malhotra and Kumari (2016) have tested the role of exports in economic growth and found that there was a positive relationship between exports and economic growth. Besides, trade liberalization has also been found to have a positive effect on economic growth, according to Heitger (1987), Edwards (1992), Harrison (1996), Greenaway (1998), Onafowora and Owoye (1998), Greenaway et al. (2001), Utkulu and Ozdemir (2004), Buehler et al. (2011), and Mercan et al. (2013).

\section{Methodology}

In this study, the vector autoregression (VAR) model will be used. This model is a statistical model that is especially useful for analyzing, describing and forecasting the behaviour of financial and economic time series. It is used for analyzing the dynamic effect of random disturbances on the variables in the system, and for forecasting a system of interrelated time series. Moreover, the VAR model is also used to evaluate the relationships between variables in the model. Furthermore, the VAR model is flexible and easy to use, and it is less restrictive than other approaches. In this study, the VAR model is used to test for cointegration and investigate the determinants of economic growth in Syria.

The economic growth model consists of six variables, namely, the gross domestic product (GDP), gross fixed capital formation of the public sector (GI), gross fixed capital formation of the private sector (PI), exports (EXP), oil price (OP), and population growth rate (GPOP) of Syria. GDP is the dependent variable. The model is presented as follows:

$$
\ln G D P=\alpha+\beta_{1} \ln G I+\beta_{2} \ln P I+\beta_{3} \ln E X P+\beta_{4} \ln O P+\beta_{5} G P O P+\epsilon_{t}
$$

where $b_{0}$ is the intercept, $b_{1}, b_{2}, b_{3}, b_{4}$, and $b_{5}$ are the slope coefficients, InGDP is the natural log of real gross domestic product (millions of SYP), InGl is the natural log of real gross fixed capital formation of the public sector (millions of SYP), InPI is the natural log of real gross fixed capital formation of the private sector (millions of SYP), InOP is the natural log of oil price (US dollars per barrel), InEXP is the natural log of real exports (millions of SYP), GPOP is the population growth rate (percent), and $\varepsilon_{t}$ is the error term.

This study uses annual time series data of Syria during the period from 1980 to 2010. These data were collected from the Central Bureau of Statistics in Syria (CBS) 
and World Bank (WB). Because this study involves time series data, it is necessary to begin the analysis with the unit root tests. Augmented Dickey-Fuller (ADF) unit root tests will be conducted on each variable in the model to find out whether the time series data are stationary at the level or first difference. After testing for stationarity and confirming the order of integration of each time series, and if the variables in the model are found to be integrated of the same order, the Johansen cointegration test will be applied to establish whether there is any long-run or equilibrium relationship between the variables in the model. If the variables are found to be cointegrated, then the Granger causality tests will be conducted based on the VECM to determine the long and short run causality relationships among the variables in the model. However, the VECM will be subjected to the residual diagnostics, namely, the normality, serial correlation, heteroskedasticity and Ramsey RESET tests first to ascertain the statistical adequacy of the model before running the Granger causality tests. On the other hand, if the Johansen test results indicate no cointegration among the variables in a particular model, then the Granger causality tests will be based on the VAR model. Lastly, Impulse response functions (IRFs) and variance decomposition (VD) analysis will be computed for the model to evaluate if the independent variables have any significant role in explaining the variation of the dependent variable at the short- and long-run forecasting horizons.

\section{Empirical Results and Discussion}

From the ADF unit root test results given in Table 1, we can see that all the six variables are not stationary at the levels, but become stationary after first differencing at least at the 5 per cent level of significance. This means that all the variables are integrated of order 1 , that is, I(1).

Table 1. ADF unit root test results

\begin{tabular}{lcccccc}
\hline & \multicolumn{3}{c}{ Level } & \multicolumn{3}{c}{ First difference } \\
\cline { 2 - 7 } ADF & Intercept & $\begin{array}{c}\text { Trend and } \\
\text { intercept }\end{array}$ & $\begin{array}{c}\text { No trend \& } \\
\text { no intercept }\end{array}$ & Intercept & $\begin{array}{c}\text { Trend and } \\
\text { intercept }\end{array}$ & $\begin{array}{c}\text { No trend \& } \\
\text { no intercept }\end{array}$ \\
\hline InGDP & 1.117441 & -1.771122 & 2.094763 & $-3.741055^{* * *}$ & $-4.786693^{* * *}$ & $-1.980987^{* *}$ \\
InGI & -0.610223 & -3.141075 & 0.403775 & -2.543227 & -3.299449 & $-2.564087^{* *}$ \\
InPI & -0.362961 & -1.744027 & 1.212235 & $-4.434971^{* * *}$ & $-4.500059^{* * *}$ & $-4.322557^{* * *}$ \\
InEXP & 0.195672 & -3.229596 & 1.815048 & $-4.748178^{* * *}$ & -2.502529 & $-4.306729^{* * *}$ \\
InOP & -0.522746 & -1.637071 & 0.492299 & $-5.903488^{* * *}$ & $-6.575602 * * *$ & $-5.929094^{* * *}$ \\
GPOP & -2.290884 & -1.677601 & -1.38462 & -1.466551 & -2.952932 & $-2.698303^{* * *}$ \\
\hline \multicolumn{2}{c}{ Note: *** Denotes significance at the 1 percent level, and ** at the 5 per cent level. } &
\end{tabular}

\subsection{Johansen Cointegration Test Results}

Since all the variables are stationary in the first difference, we can determine the presence of any cointegration or long-run relationship among the variables based on the Johansen cointegration test. However, before running the cointegration test, we run the VAR model first to determine the optimal lag length, based on the 
minimum Akaike Information Criterion (AIC). Due to the limited number of observations, the maximum lag has been set to 2 in the lag length selection process. The optimal lag length is 2 lags based on the AIC.

After having determined the number of lags, we then proceed with the cointegration test for the model. Table 2 shows that there are five cointegration equations based on the trace test and four cointegration equations based on the maximum eigenvalue test. In other words, the results indicate more than one longrun relationship exist among the variables in the system comprising InGDP, InGI, InPI, InEXP, InOP, and GPOP.

\section{Table 2. Johansen cointegration test results}

\begin{tabular}{ccccc}
\hline No. of CE(s) & Trace Statistic & Prob & Max-Eigen Statistic & Prob \\
\hline$r=0$ & $235.2160^{* * *}$ & 0.0000 & $81.29044^{* * *}$ & 0.0000 \\
$r \leq 1$ & $153.9256^{* * *}$ & 0.0000 & $70.83062 * * *$ & 0.0000 \\
$r \leq 2$ & $83.09497^{* * *}$ & 0.0000 & $30.52071 * *$ & 0.0279 \\
$r \leq 3$ & $52.57427^{* * *}$ & 0.0003 & $29.59086^{* * *}$ & 0.004 \\
$r \leq 4$ & $22.98340^{* *}$ & 0.0206 & 15.80006 & 0.0517 \\
$r \leq 5$ & 7.183347 & 0.1171 & 7.183347 & 0.1171 \\
\hline
\end{tabular}

Note: ${ }^{* *}$ Denotes significance at the 1 percent level, and ${ }^{* *}$ at the 5 per cent level

Since there are more than one cointegration relationship between the variables, the cointegrating equation that we have selected to explain the economic growth in Syria is the one that seems to support the theoretical a priori expectations with regard to the sign of the respective variables in the economic growth model. The cointegrating equation was normalized using the real GDP variable. Table 3 shows the normalized cointegrating vector.

Table 3. Cointegration equation normalized with respect to GDP

\begin{tabular}{ccccccc}
\hline $\operatorname{lnGDP}$ & $\operatorname{InGI}$ & $\operatorname{InPI}$ & $\operatorname{InEXP}$ & $\operatorname{InOP}$ & GPOP & $\mathrm{C}$ \\
\hline 1.000000 & -0.536766 & -0.420254 & -0.142589 & -0.146249 & -0.161863 & 1.408858 \\
& $(0.02332)$ & $(0.03781)$ & $(0.02392)$ & $(0.02321)$ & $(0.02953)$ & $(1.00665)$ \\
\hline
\end{tabular}

From Table 3, the long-run InGDP equation can be written as:

$$
\begin{gathered}
\ln G D P=-1.408+0.536 \ln G I+0.420 \ln P I+0.142 \ln E X P+0.146 \ln O P \\
+0.161 G P O P
\end{gathered}
$$

The cointegration equation given by equation (2) above shows that the InGDP is positively related to $\ln G I, \operatorname{InPI}, \operatorname{InEXP}$, InOP and GPOP.

The coefficient of InGI indicates that for every one percent increase in public sector investment, the GDP of Syria will increase by 0.54 percent. Furthermore, the coefficient of InPI signifies that for every one percent increase in private sector investment, the GDP will increase by 0.42 percent. These results suggest that both public and private sector investments play important roles in Syria's economic growth. The public sector supports the local economy by creating the infrastructure 
that contributes to achieving economic development, and establishing projects that the private sector cannot or is unwilling to undertake due to the huge financial costs and lack of profits that can be derived from these projects. Besides, based on the socialist direction of the Syrian economy since 1963, the government has adopted the policy of nationalization, offered free education to every child in the country, and provided free health services to its citizens. However, since the year 2000, the government has been working towards gradually reforming the Syrian economy from central planning towards a social market economy by creating an attractive investment climate. Hence, the public sector has been playing a central role in the Syrian economy.

On the other hand, the private sector buttresses the national economy by creating new job opportunities and producing goods and services for domestic consumption and export, which reflected positively on the local economy. The Syrian government has also engaged the private sector in various economic activities by giving it a bigger role in the local economy. For example, the government has allowed the private sector to invest in certain industries that were earlier only state-owned, such as cement and sugar production. In addition, the government has allowed the private sector to invest in private higher education, print newspapers and magazines, establish commercial radio stations, and create private banks, Islamic banks, and insurance companies. Our finding is in line with the results of Ghura (1997), Ramirez and Nazmi (2003), Bukhari et al. (2007), Aka (2007), Kandenge (2010), and Fatima (2012). These studies also found that public and private sector investment have positive effects on economic growth.

The coefficient on InEXP indicates that for every one percent increase in exports, the GDP will increase by 0.14 percent. An increase in exports leads firms to increase their output, enhance their production, and boost both local and foreign investments in the country. In addition, exports supply the state budget with earnings and foreign currency that can be utilized for importing capital and intermediate goods. Furthermore, the Syrian government has been seeking to transform the Syrian economy from a relatively low productivity economy to an economy with a competitive production capacity, by improving the production base, creating an attractive investment climate, applying modern technology to develop production and trading with different countries. Hence, exports play a vital role in promoting economic growth in the country. This result is similar to the results obtained by Tyler (1981), Balassa (1985), Krueger (1990), Singupta and Espana (1994), Shirazi and Abdul-Manap (2004), Alhajhoj (2007), Hye and Bel Haj Boubaker (2011), and Saad (2012).

The coefficient on InOP denotes that when the oil price increases by one percent, the GDP will increase by 0.15 percent. A higher oil price motivates Syria to increase its oil production, which leads to the increase in its GDP. Moreover, oil exports contribute a high percentage share of total Syrian exports, and two thirds of Syrian foreign exchange earnings come from the oil sector. Increase in the oil price will 
boost total Syrian exports, which in turn improves the trade balance, fills the export-import gap, and generates revenue growth and foreign exchange inflows. Besides, high oil prices do attract investors to invest in the oil industry. Hence, a boost to oil prices does have a positive impact on the economic growth of the country. On the other hand, when oil prices fall, Syria will see a reduction in export revenue and this will have a negative impact on its economy. Similar results were also borne by Ito (2008), El-Anshasy (2009), Aliyu (2009), Yong et al. (2011), and Emami and Adibpour (2012), who indicated that a rise in oil prices affects positively the economic growth of oil-exporting countries.

The coefficient on GPOP indicates that for every 0.01 percent increase in the population growth rate, the GDP will increase by 0.162 percent. Population growth is the main source of labor supply. In addition, with population growth, the domestic consumption and demand for various goods and services in the country will also increase in tandem. Akin to other developing countries, most production activities in Syria are labour-intensive activities, so increases in the population can boost production, which will in turn affect positively on the economic growth of the country. Our result is consistent with the new growth theory, which assumes that population growth can be an important source of economic growth. Likewise, Savas (2008), Furuoka (2009) and Furuoka and Munir (2011) found that population growth has positive effects on economic growth.

\subsection{Statistical Diagnostic Tests Results}

Since the variables in the model are cointegrated, we have estimated the VECM to model the short-run dynamics. However, it is essential to subject the VECM to a number of diagnostic tests, namely, the normality, serial correlation, heteroskedasticity and Ramsey RESET to ascertain the model's statistical adequacy. A $5 \%$ level of significance will be used in all these tests.

The results of the diagnostic tests are reported in Table 4. The VECM with InGDP and InEXP as the dependent variables passed the normality, heteroskedasticity (BPG and ARCH) and Ramsey RESET tests, but did not pass the serial correlation LM test.

However, the VECM with InGI, InPI, InOP, and GPOP as the dependent variable passed the normality, serial correlation, heteroskedasticity (BPG and ARCH) and Ramsey RESET tests. The serial correlation problem may be due to the insufficient number of lags in the VECM. However, after increasing the lag length, the serial correlation problem still persists. Given the limited number of observations, it is not possible to further increase the lag length. Therefore, the serial correlation problem has been corrected using the Newey-West HAC (heteroskedasticityautocorrelation consistent) standard errors before proceeding with the $t$ and $F$ tests for long-run and short-run Granger causality. 
Adel Shakeeb MOHSEN, Soo Y. CHUA \& Che Normee CHE SAB

Table 4. Results of the statistical diagnostic tests on the VECM

\begin{tabular}{lcccccc}
\hline \multicolumn{7}{c}{ Dependent variables } \\
\hline & InGDP & InGI & InPI & $\operatorname{lnEXP}$ & InOP & GPOP \\
\hline \multirow{2}{*}{ JB test } & 0.595766 & 0.344216 & 4.020530 & 0.552649 & 2.035149 & 0.583155 \\
& $(0.742388)$ & $(0.841888)$ & $(0.133953)$ & $(0.758567)$ & $(0.361471)$ & $(0.747084)$ \\
LM test & $1.630891(2)^{* *}$ & $1.044018(2)$ & $0.010215(2)$ & $2.848510(2)^{* *}$ & $0.235888(2)$ & $0.537605(2)$ \\
& $(0.0019)$ & $(0.1256)$ & $(0.9189)$ & $(0.0001)$ & $(0.3260)$ & $(0.1002)$ \\
BPG test & 1.851489 & 1.350987 & 0.394113 & 0.845348 & 0.302289 & 0.762566 \\
& $(0.2861)$ & $(0.2725)$ & $(0.7232)$ & $(0.4444)$ & $(0.8779)$ & $(0.5081)$ \\
ARCH test & $1.540999(1)$ & $0.165130(1)$ & $1.523327(1)$ & $0.532549(1)$ & $0.053530(1)$ & $0.787674(1)$ \\
& $(0.2099)$ & $(0.6738)$ & $(0.2125)$ & 0.4514 & $(0.8096)$ & $(0.3629)$ \\
RESET test & $0.055651(1)$ & $4.203823(1)$ & 0.968691 & $0.000540(1)$ & $0.395427(1)$ & $1.281751(1)$ \\
& $(0.8251)$ & 0.0611 & $(0.3807)$ & $(0.9829)$ & $(0.7062)$ & $(0.3008)$ \\
\hline
\end{tabular}

Note: ** Denotes significance at the 1 percent level, and ${ }^{*}$ at the 5 per cent level.

\subsection{Granger Causality Tests Results}

After the VECM was subjected to the residual and stability diagnostics, the Granger causality tests based on the VECM are used to examine the short- and long- run causality relationships among the variables in the model. The F-test results show the significance of the short-run causal effects, while the significance of the coefficient of the lagged error correction term [ect(-1)] shows the long-run causal effect.

It is clear from Table 5 that the F-statistics for the short-run dynamics reveal bidirectional causality relationships between InGI and InGDP, and InPI and InGDP. The results suggests that both public and private sector investment Granger cause economic growth in Syria through improved and increased production, and economic growth in turn creates an attractive investment climate in the country, which motivates producers (in the public and private sectors) to increase their investments in the country.

\section{Table 5. Granger causality test results}

\begin{tabular}{lccccccc}
\hline \multicolumn{7}{c}{ Independent variables } \\
\hline & $\sum \Delta \operatorname{lnGDP}$ & $\sum \Delta \operatorname{lnGI}$ & $\sum \Delta \operatorname{lnPI}$ & $\sum \Delta \operatorname{lnEXP}$ & $\sum \Delta \operatorname{lnOP}$ & $\sum \Delta \mathrm{GPOP}$ & ect(-1) \\
\hline$\Delta \operatorname{lnGDP}$ & - & $12.02(2)^{* *}$ & $33.36(2)^{* *}$ & $40.04(6)^{* *}$ & $11.44(3)^{* *}$ & $13.66(3)^{* *}$ & $-2.09^{*}$ \\
$\Delta \operatorname{lnGI}$ & $3.74(2)^{* *}$ & - & $3.29(2)^{* *}$ & $2.10(2)$ & $2.36(2)^{*}$ & $1.66(2)$ & $-2.37^{* *}$ \\
$\Delta \operatorname{lnPI}$ & $7.20(3)^{* *}$ & $11.98(3)^{* *}$ & - & $3.72(5)^{* *}$ & $1.58(3)$ & $1.54(2)$ & $-3.74^{* *}$ \\
$\Delta \operatorname{lnEXP}$ & $11.09(5)^{* *}$ & $8.06(2)^{* *}$ & $4.17(3)^{* *}$ & - & $12.92(3)^{* *}$ & $31.98(3)^{* *}$ & -1.92 \\
$\Delta \operatorname{lnOP}$ & $6.95(4)^{* *}$ & $3.20(2)^{* *}$ & $5.73(3)^{* *}$ & $5.26(3)^{* *}$ & - & $8.90(4)^{* *}$ & $-2.57^{* *}$ \\
$\Delta \mathrm{GPOP}$ & $3.81(3)^{* *}$ & $3.89(3)^{* *}$ & $1.33(2)$ & $0.24(2)$ & $0.88(4)$ & - & $-2.27^{*}$ \\
\hline
\end{tabular}

Notes: ect(-1) represents the error correction term lagged one period. The numbers in the brackets show the optimal lag based on the AIC. $\Delta$ represents the first difference. Only F-statistics for the explanatory lagged variables in first differences are reported here. For the ect(-1) the t-statistic is reported instead. ${ }^{* *}$ denotes significance at the 5 per cent level and ${ }^{*}$ indicates significance at the 10 per cent level. 
Table 5 also shows a bidirectional causality relationship between InEXP and InGDP. Exports motivate producers to raise and improve their production, which can boost economic growth in the country, and higher economic growth motivates producers to expand their production and exports. There is also a bidirectional causality relationship between InOP and InGDP. This outcome implies the significance of the oil sector in the Syrian economy, and the effect of oil price on production costs and hence GDP growth.

Furthermore, there is a bidirectional causality relationship between GPOP and InGDP. Population growth supports production activities with a bigger labor force, and increases the local demand for various goods and services, which motivates producers to increase their production in the country. At the same time, higher economic growth leads to improvements in the standard of living in the country, which causes population growth in the country. There are also bidirectional longrun causality relationships between $\ln G I, \ln P I, \operatorname{lnOP}$, GPOP and $\ln G D P$, and unidirectional long-run causality relationship running from InEXP to InGDP, which agrees with the export-led growth theory.

\subsection{Impulse Response Functions (IRFs) Results}

Impulse response functions (IRFs) are used to study the dynamic effects of a particular variable's shock on the other variables that are included in the same model. Besides, we can examine the dynamic behaviour of the time series over a ten-year forecast horizon. Furthermore, through the IRF we can know whether the response of one variable to changes in other variables is positive or negative and whether it is significant or not. If the point estimate of the IRF is above the zero line, this means that the response is positive, and if the point estimate of the IRF is below the zero line the response is negative. Besides, if the point estimate of the IRF passes through the zero line, the response is insignificant. There are many options for transforming the impulses. We will use the generalized impulse response functions (GIRF).

Figure 2 shows that InGDP responds negatively to a shock in InGI after the first year and the impact of the shock does not die down even after 10 years. This means that there is a negative long term effect of a shock to GI on GDP growth. However, a shock to InPI has a positive effect on InGDP and the effect is permanent. These results indicate that the Syrian government should attempt to encourage private sector investment and improve public sector investment in the country.

Both public and private investment should be focused on increasing productive capacity, enhancing productivity and competitiveness as well as improving infrastructure and social amenities.

There is also a positive long term effect of an export shock on GDP growth, which is consistent with the export-led growth theory, and shows the important role of exports in supporting Syrian economic growth. Furthermore, InGDP responds 
positively to a shock to InOP in the first five years and then it responds negatively in the following years. Since oil price has a negative effect on GDP in the long run, it is crucial that the government reduces its dependence on oil exports, and keep it as reserve stock that can be utilized later for domestic production activities in order to circumvent the negative impact of high oil prices on the national economy in the future. Lastly, a shock to GPOP will have a negative effect on InGDP, which increases over time. Given this result, it is judicious to improve the quality of human capital in the country in order to increase the supply of highly skilled and knowledgeable workforce, and use modern technology in the production activities to boost productivity, competiveness, and growth of the Syrian economy.

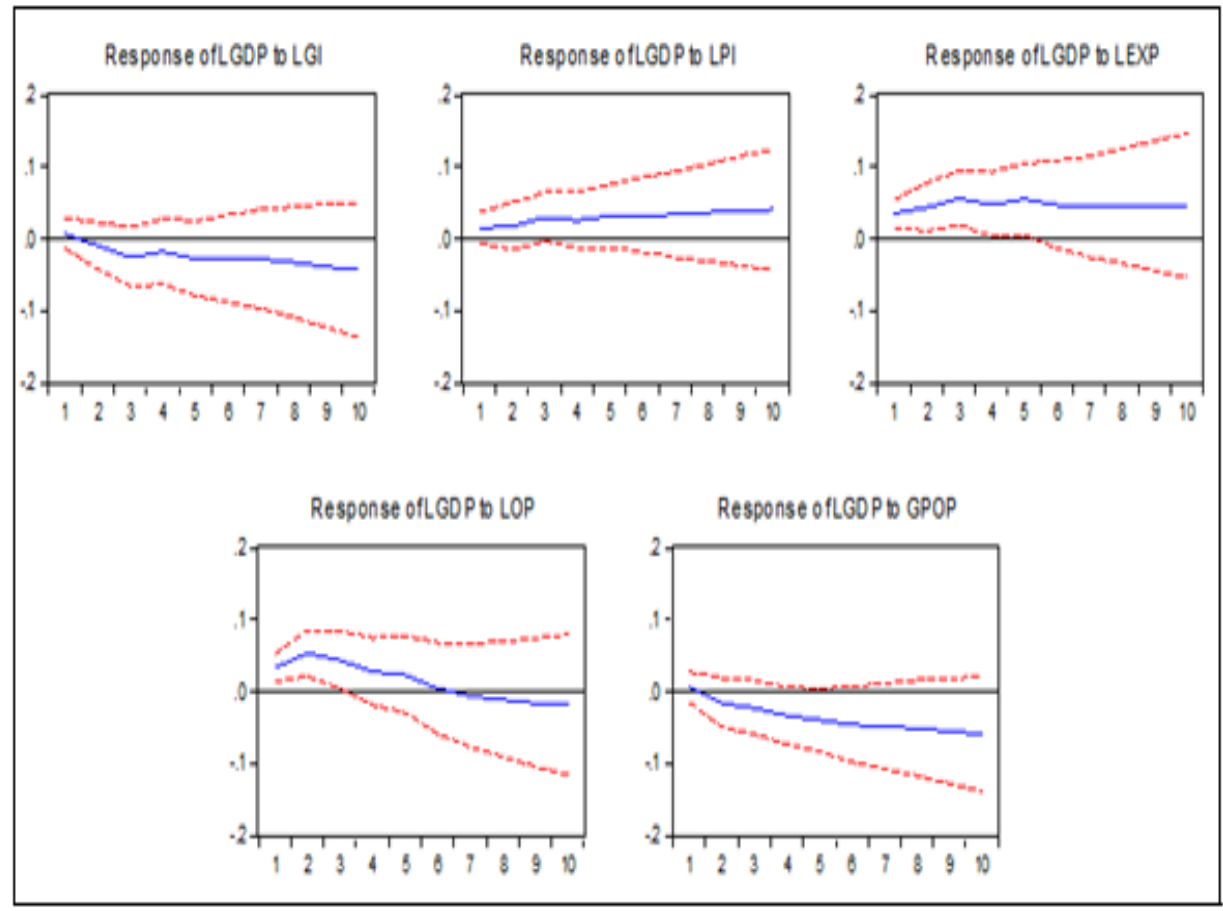

Figure 2. Generalized impulse response functions (GIRF) results

\subsection{Variance Decomposition (VD) Analysis}

The forecast error variance decompositions (VD) for the 1- to 10-year forecast horizons are examined to explain how much of the forecast error variance of InGDP can be explained by its own shocks and shocks to the other variables in the InGDP model at the various the forecast horizons. Table 6 reports the percentages of the forecast error variances accounted for by each shock. 


\section{Table 6. Variance decomposition (VD) analysis}

\begin{tabular}{cccccccc}
\hline Period & S.E. & InGDP & InGI & InPI & $\operatorname{InEXP}$ & $\operatorname{InOP}$ & GPOP \\
\hline 1 & 0.056572 & 100.0000 & 0.000000 & 0.000000 & 0.000000 & 0.000000 & 0.000000 \\
2 & 0.083457 & 82.73526 & 3.623831 & 0.143563 & 0.928451 & 7.843377 & 4.725521 \\
3 & 0.104441 & 73.72134 & 11.35003 & 0.316886 & 3.035326 & 5.225706 & 6.350713 \\
4 & 0.118436 & 63.91311 & 12.10663 & 1.070928 & 7.830690 & 4.477857 & 10.60079 \\
5 & 0.135778 & 51.98381 & 14.27217 & 1.902878 & 13.86591 & 5.342010 & 12.63322 \\
6 & 0.154391 & 40.62437 & 14.59406 & 3.363916 & 17.83489 & 9.189226 & 14.39353 \\
7 & 0.173753 & 32.07718 & 14.14725 & 4.794506 & 20.86710 & 13.24414 & 14.86982 \\
8 & 0.194810 & 25.61158 & 14.03344 & 5.971281 & 22.88858 & 16.82149 & 14.67363 \\
9 & 0.217358 & 20.92680 & 14.18505 & 6.859429 & 24.02622 & 19.77022 & 14.23228 \\
10 & 0.240658 & 17.67064 & 14.60472 & 7.482165 & 24.82046 & 21.67682 & 13.74519 \\
\hline
\end{tabular}

At shorter forecasting horizons, GDP shocks explains a very high percentage of its forecast error variance. In contrast, at the 10th year forecast horizon, $25 \%$ of the forecast error variance of InGDP is explained by innovations in InEXP and $22 \%$ by innovations in InOP. However, innovations in InPI, InGI and GPOP account for only $7.5 \%, 15 \%$ and $14 \%$ of the forecast error variance of InGDP respectively, while innovations in InGDP itself explained only $17.7 \%$ of its forecast error variance. Furthermore, we can see that the relative contribution of $\ln \mathrm{GI}, \ln \mathrm{PI}, \ln E X P$ and GPOP shocks on InGDP increased as the forecasting horizon expands, while the contribution of a InOP shock declined in the first four years and then started to rise from the fifth to the tenth year forecasting horizons. Moreover, the contribution of InGI shock is greater in explaining the variation in InGDP forecast error variance in the medium term horizons ( $2-5$ years), while the contribution of InEXP shock is more significant at longer term forecasting horizons (6-10 years). In contrast, the proportion of the variation in InGDP which is attributable to its own shock decreases steadily over the same forecasting horizons.

\section{Conclusion}

This study investigated the determinants of economic growth in Syria using annual time series data from 1980 to 2010 . The model consists of six variables, with the GDP as the dependent variable and public sector investment, private sector investment, exports, oil price, and population growth rate as the independent variables. The ADF unit root test, Johansen cointegration test, Granger causality tests, impulse response functions (IRF), and variance decomposition (VD) analysis were used in this study. The ADF test results indicate all variables are I(1). The Johansen cointegration test showed that public sector investment, private sector investment, exports, oil price, and population growth rate have positive long-run relationships with GDP. Furthermore, from the Granger causality tests, we found that there are bidirectional long-run causality relationships between public sector investment, private sector investment, oil price, population growth rate and GDP. There is also evidence of unidirectional long-run causality relationship running from exports to GDP. While in the short run, there are bidirectional short-run causality 
relationships between public sector investment, private sector investment, exports, oil price, population growth rate and GDP.

The impulse response functions (IRFs) indicated that when there is a shock to public sector investment or population growth rate, GDP will respond negatively in the following years. However, when there is a shock to private sector investment or exports, GDP will respond positively in the following years. Furthermore, when there is a shock to oil price, GDP will respond positively in the first five years, followed by a negative response in the following years. The variance decomposition (VD) analysis showed that at a ten-year forecasting horizon, $25 \%$ of the forecast error variance of GDP is explained by exports, while $22 \%, 15 \%, 14 \%$ and $7.5 \%$ of the GDP forecast error variance are explained by oil price, public sector investment, population growth rate and private sector investment variations, respectively.

Based on the results of this study, after the war in Syria, it is necessary to rebuild what was destroyed through improving the Syrian industry, increasing productivity, and improving the quality and competitiveness of the Syrian products in both the local and global markets. The quality of its exports must be able to compete with foreign products in the global markets. It is important also to reduce the dependence on raw material for manufacturing exports and increase the exports of finished products to decrease the impact of raw material price fluctuations on the Syrian economy, and to exploit the raw materials in national industries. Moreover, the government needs to reduce the level of bureaucracy, improve the performance of the public sector, and boost the private sector. Furthermore, human capital development has an important role in the Syrian economy. The government must work to improve the human capital by improving educational standards, health services, infrastructure and the standard of living, as well as provide training to the workforce to upgrade their qualifications and skills for better work performance.

Finally, the Syrian government should work to strengthen the domestic growth factors in the Syrian economy to achieve the required growth, through lessening the role of central planning in the Syrian economy, creating an attractive investment climate in the country, improving the performance and efficiency of the public sector, increasing private sector investment, improving the levels of industrial and agricultural productivity, diversifying exports, and improving the human capital in the country. Last but not least, there is the urgent need for political stability in the country.

\section{References}

Abou-Stait, F. (2005). Are Exports the Engine of Economic Growth? An Application of Cointegration and Causality Analysis for Egypt, 1977-2003. Tunis: African Development Bank.

Afzal, M. (2009). Population Growth and Economic Development in Pakistan. The Open Demography Journal, 2, 1-7. https://doi.org/10.2174/1874918600902010001 
Aka, B. F. (2007). Relative Effects of Private and Public Investment on Côte D'lvoire's Economic Performance. Applied Econometrics and International Development, 7 (1), 151158.

Alhajhoj, H. (2007). Exports and Economic Growth in Saudi Arabia: A VAR Model Analysis. Journal of Applied Sciences, 7 (23), 3649-3658. https://doi.org/10.3923/jas.2007.3649.3658

Aliyu, S. U. (2009). Impact of Oil Price Shock and Exchange Rate Volatility on Economic Growth in Nigeria: An Empirical Investigation. Research Journal of Internatıonal Studıes (11), pp. 4-15.

Al-Yousif, Y. K. (1997). Exports and Economic Growth: Some Empirical Evidence from the Arab Gulf Countries. Applied Economics, 29 (6), 693- 697. https://doi.org/10.1080/000368497326624

Balassa, B. (1985). Exports, Policy Choices, and Economic Growth in Developing Countries After the 1973 Oil Shock. Journal of Development Economics, 18, 23-35. https://doi.org/10.1016/0304-3878(85)90004-5

Berument, H., Ceylan, N. B., \& Dogan, N. (2010). The Impact of Oil Price Shocks on the Economic Growth of the Selected MENA Countries. The Energy Journal, 31 (1), 149-176.

Boris, R. E. (1987). A Country Study: Syria-The Economy [online]. [Accessed 20th July 2011]. Available from World Wide Web: http://lcweb2.loc.gov/frd/cs/sytoc.html\#sy0077

Buehler, S., Helm, M., \& Lechner, M. (2011). Trade Liberalization and Growth: Plant-Level Evidence from Switzerland. University of St. Gallen: School of Economics and Political Science.

Bukhari, S. A., Ali, L., \& Saddaqat, M. (2007). Public Investment and Economic Growth in the Three Little Dragons: Evidence from Heterogeneous Dynamic Panel Data. International Journal of Business and Information, 7 (1), 57-79.

Burbidge, J., \& Harrison, A. (1984). Testing for the Effects of Oil-Price Rises Using Vector Autoregressions. International Economic Review, 25, 459-484. https://doi.org/10.2307/2526209

Central Bureau of Statistics (CBS). (2003-2010), Syria, Damascus. Retrieved form http://www.cbssyr.org

Darby, M. R. (1982). The Price of Oil and World Inflation and Recession. American Economic Review, 72,738-751.

Dawson, D. J., \& Tiffin, R. (1998). Is There a Long-Run Relationship between Population Growth and Living Standard? The Case of India. Journal of Development, 34 (5), 149-156. https://doi.org/10.1080/00220389808422540

Edwards, S. (1992). Trade Orientation, Distortions and Growth in Developing Countries. Journal of Development Economics, 39 (1), 31-57. https://doi.org/10.1016/03043878(92)90056-F

El-Anshasy, A. A. (2009). Oil Prices and Economic Growth in Oil Exporting Countries. UAE: College of Business and Economics, United Arab Emirates University.

El-Quqa, O. M., Hasan, F., Gupta, S., \& Joubaili, A. (2007). Syria Economic \& Strategic Outlook. Kuwait: Global Investment House KSCC.

Emami, K., \& Adibpour, M. (2012). Oil Income Shocks and Economic Growth in Iran. Economic Modelling (29), 1774-1779. https://doi.org/10.1016/i.econmod.2012.05.035 
Fatima, G. (2012). Joint Impact of Investment (Public and Private) on the Economic Growth of Pakistan: (Co-Integration Approach). International Journal of Humanities and Social Science, 2 (15), 171-176.

Furuoka, F. (2009). Population Growth and Economic Development: New Empirical Evidence from Thailand. Economics Bulletin, 29 (1), 1-14.

Furuoka, F., \& Munir, Q. (2011). Can Population Growth Contribute to Economic Development? New Evidence from Singapore. Economics Bulletin, 31 (4), 3226-3239.

Ghali, K. H. (1998). Public Investment and Private Capital Formation in a Vector Error Correction Model of Growth. Applied Economics, 30 (6), 837-844. https://doi.org/10.1080/000368498325543

Ghura, D. (1997). Private Investment and Endogenous Growth: Evidence from Cameroon. IMF Working Paper, 97 (165), 1-31. https://doi.org/10.5089/9781451980004.001

Gisser, M., \& Goodwin, T. H. (1986). Crude Oil and the Macroeconomy: Tests of Some Popular Notions. Journal of Money, Credit and Banking, 18, 95-103. https://doi.org/10.2307/1992323

Greenaway, D. (1998). Does Trade Liberalisation Promote Economic Development? Scottish Journal of Political Economy, 45 (5), 491-511. https://doi.org/10.1111/1467-9485.00109

Greenaway, D., Morgan, W., \& Wright, P. (2001). Trade Liberalisation and Growth in Developing Countries. Journal of Development Economics, 67 (1), 229-244. https://doi.org/10.1016/S0304-3878(01)00185-7

Hamilton, J. D. (1983). Oil and the Macroeconomy Since World War II. Journal of Political Economy, 91, 593-617. https://doi.org/10.1086/261140

Harrison, A. (1996). Openness and Growth: A Time-Series, Cross-Country Analysis for Developing Countries. Journal of Development Economics, 48 (2), 419- 447. https://doi.org/10.1016/0304-3878(95)00042-9

Heitger, B. (1987). Import Protection and Export Performance: Their Impact on Economic Growth. Weltwirtschaftliches Archiv, 123 (2), 249-261. https://doi.org/10.1007/BF02706662

Hye, Q. M., \& Bel Haj Boubaker, H. (2011). Exports, Imports and Economic Growth: An Empirical Analysis of Tunisia. The IUP Journal of Monetary Economics, IX (1), 6-21.

Ibrahim, M. H. (2000). Public and Private Capital Formation and Economic Growth in Malaysia, 1961-1995. IIUM Journal of Economics and Management, 8 (1), 21-40.

Ito, K. (2008). Oil Price and the Russian Economy: A VEC Model Approach. International Research Journal of Finance and Economics (17), 68-74.

Kafri, M. (2004). Characteristics of the Syrian Economy and Development Experience [online]. Retrieved from http://www. ahewar.org/debat/show.art.asp?aid=22619 on August 28, 2011.

Kandenge, F. T. (2010). Public and Private Investment and Economic Growth in Namibia (1970-2005). Botswana Journal of Economics (BOJE), 7 (11), 2-15.

Khan, A., \& Saqib, N. (1993). Exports and Economic Growth: The Pakistan Experience. International Economic Journal, 7 (3), 53-64. https://doi.org/10.1080/10168739300080020

Krueger, A. (1990). Asian Trade and Growth Lessons. AEA Papers and Proceedings, 80, 108112. 
Malhotra, N., \& Kumari, D. (2016). Export Performance and Economic Growth in East Asian Economies - Application of Cointegration and Vector Error Correction Model. Eurasian Journal of Business and Economics, 9 (18), 135-152.

Mercan, M., Gocer, I., Bulut, S., \& Dam, M. (2013). The Effect of Openness on Economic Growth for BRIC-T Countries: Panel Data Analysis. Eurasian Journal of Business and Economics, 6 (11), 1-14.

Mushtaq, K. (2006). Population Growth and Economic Development: Test for Causality. The Lahore Journal of Economics, 11 (2), 71-77.

Onafowora, O. A., \& Owoye, O. (1998). Can Trade Liberalization Stimulate Economic Growth in Africa? World Development, 26 (3), 497-506. https://doi.org/10.1016/S0305750X(97)10058-4

Ram, R. (1987). Exports and Economic Growth in Developing Countries: Evidence from TimeSeries and Cross-Section Data. Economic Development and Cultural Change, 36, 51-72. https://doi.org/10.1086/451636

Ramirez, M. D., \& Nazmi, N. (2003). Public Investment and Economic Growth in Latin America: An Empirical Test. Review of Development Economics, 7 (1), 115-126. https://doi.org/10.1111/1467-9361.00179

Saad, W. (2012). Causality between Economic Growth, Export, and External Debt Servicing: The Case of Lebanon. International Journal of Economics and Finance, 4 (11), 134-143. https://doi.org/10.5539/ijef.v4n11p134

Savas, B. (2008). The Relationship between Population and Economic Growth: Empirical Evidence from the Central Asian Economies. OAKA, 3 (6), 161-183.

Seifan, S. (2009). The Social Consequences of the Economic Policies in Syria. Damascus: Syrian Economic Sciences Association.

Sengupta, J., \& Espana, J. (1994). Exports and Economic Growth in Asian NICS: An Econometric Analysis for Korea. Applied Economics, 26, 41-51. https://doi.org/10.1080/00036849400000060

Shirazi, N. S., \& Abdul-Manap, T. A. (2004). Exports and Economic Growth Nexus: The Case of Pakistan. The Pakistan Development Review, 43 (4), 563-581.

Syrian Centre for Policy Research (SCPR). (2014). Socioeconomic Monitoring Report on Syria. Damascus: Syrian Centre for Policy Research (SCPR).

Syrian-Italian Economic Directory (SIED). (2011). Definition of the Syrian Economy. Retrieved from http://www.it-sy.com/pages/arabic pages/articles/articles/article $2 \mathrm{ar}$.htm on July 28, 2011.

Thornton, J. (2001). Population Growth and Economic Growth: Long-Run Evidence. Southern Economic Journal, 68 (2), 464-468. https://doi.org/10.2307/1061606

Trang, P. T., \& Hieu, T. H. (2011). Effects of Population Growth on Economic Growth in Asian Developing Countries. Bachelor's Project in Economics, Malardalen University.

Tyler, W. (1981). Growth and Export Expansion in Developing Countries. Journal of Development Economics, 9, 121-130. https://doi.org/10.1016/0304-3878(81)90007-9

United Nations Industrial Development Organization (UNIDO). (2009). Independent Evaluation: Syrian Arab Republic. Vienna: United Nations Industrial Development Organization. 
Adel Shakeeb MOHSEN, Soo Y. CHUA \& Che Normee CHE SAB

U.S. Department of State (USDS). (2011). 2010 Background Note: Syria. Retrieved from http://www.state.gov/r/pa/ei/bgn/3580.htm on July 22, 2011.

Utkulu, U., \& Ozdemir, D. (2004). Does Trade Liberalization Cause a Long Run Economic Growth in Turkey. Economic Change and Restructuring, 37 (3), 245-266. https://doi.org/10.1007/s10644-005-8080-8

Yong, L. C., Fung, N. C., \& Pui, P. Y. (2011). Oil Price and Economic Growth : Evidence from 10 Sub-Saharan Africa Countries. The Final Year Project of Bachelor's Degree, Universiti Tunku Abdul Rahman (UTAR). 